\title{
Purification and characterisation of intracellular alpha-galactosidases from Acinetobacter sp.
}

\author{
Sirisha E $\cdot$ Ravichandra Potumarthi • \\ Naveen A · Lakshmi Narasu Mangamoori
}

Received: 14 November 2014/ Accepted: 22 February 2015/Published online: 20 March 2015

(C) The Author(s) 2015. This article is published with open access at Springerlink.com

\begin{abstract}
Two alpha-galactosidases (Ag-I \& Ag-II) were purified from Acinetobacter sp. Both the enzymes were monomeric with $\mathrm{pH}$ optima of 7.0 and molecular weight of $65 \mathrm{kDa}$ for Ag-I and $37 \mathrm{kDa}$ for Ag-II. The temperature optima for Ag-I was between 50 and $60{ }^{\circ} \mathrm{C}$ and that of $\mathrm{Ag}$ II was $40{ }^{\circ} \mathrm{C}$. Both the enzymes were strongly inhibited by metal ions $\mathrm{Ag}^{2+}$ and $\mathrm{Hg}^{+}$, pCMB and SDS (1\%). The enzymes were found to be active on both natural and synthetic substrates. Artificial substrate, $p$ NPGal, has shown more affinity to enzyme than natural substrate raffinose. The half-life $\left(t_{1 / 2}\right)$ of Ag-I varied from $1.85 \mathrm{~h}$ at $90{ }^{\circ} \mathrm{C}$ to $7.6 \mathrm{~h}$ at $70{ }^{\circ} \mathrm{C}$.
\end{abstract}

Keywords $\alpha$-Galactosidases - Acinetobacter .

Purification $\cdot$ Multiple forms

$\begin{array}{ll}\text { Abbreviations } \\ \text { SDS } & \text { Sodium dodecyl sulphate } \\ \text { pNPGal } & p \text {-Nitrophenyl- } \alpha \text {-D-galactopyranoside } \\ \text { pCMB } & \text { Para-chloromercuribenzoic acid } \\ \text { kDa } & \text { Kilo Dalton }\end{array}$

S. E · N. A · L. N. Mangamoori $(\bowtie)$

Centre for Biotechnology, Institute of Science and Technology, Jawaharlal Nehru Technological University Hyderabad,

Hyderabad, Telangana, India

e-mail: mangamoori@gmail.com

R. Potumarthi

School of Agriculture, Food and Wine, The University of

Adelaide, Waite Campus, Urbrae, SA 5064, Australia

\section{Introduction}

In recent years, a substantial amount of interest has been generated on carbohydrate-cleaving enzymes due to their potential industrial and therapeutic applications. $\alpha$-Galactosidases are enzymes that belong to family of glycosyl hydrolases. Based on aminoacid sequences, alpha-galactosidases are included in four different families- GH4, GH27, GH36 and GH57 (Naumoff 2001). Most of the known bacterial and eukaryotic alpha-galactosidases with confirmed activity belong to GH27 and GH36, which constitute a superfamily (clan GH D) (Naumoff 2004).

$\alpha$-Galactosidases catalyse hydrolysis of terminal $\alpha-1-6$ linked galactose residues from different galactooligosaccharides, glycosphingolipids and glycoproteins (Dey and Pridham 1972) and also show transgalactosylation (Kato et al. 1982) and hemagglutination activity (del Campillo and Shannon 1982). Due to its diverse catalytic activity, the enzyme is used in food processing industry for improvement of nutritional value of legumes and animal feeds by removing the flatulence-causing factors (Patil et al. 2010), in beet sugar industry for crystallisation of sugars (Yamane $1971)$ and $\alpha$-galactosidase producing organisms as probiotic (Chen and Mustapha 2012; Liu et al. 2014). Recombinant alpha-galactosidases such as Fabrazyme ${ }^{\mathrm{TM}}$ and Replagal $^{\mathrm{TM}}$ are being currently employed in the treatment of Fabry's disease which is a rare X-linked lysosomal storage disorder (Tsuboi and Yamamoto 2012; Desnick 2004). The enzyme was reported to be applied for the conversion of Type 'B' erythrocytes to Type 'O' erythrocytes (Gao et al. 2011) and also in xenotransplantation (Zeyland et al. 2013). This enzyme is also used in bleaching of softwood in the paper industry (Clarke et al. 2000). 
Although $\alpha$-galactosidases were isolated and purified from various organisms (Singh and Kayastha 2012; Puchart et al. 2001; Saishin et al. 2010; Gao and Arthur 1999), the versatility of this enzyme and the demand for stable $\alpha$-galactosidase are constantly increasing despite the availability. The present work was taken up to isolate and purify thermostable $\alpha$-galactosidase from Acinetobacter sp., which will be later applied in degradation of galactooligosaccharides to increase nutritive value of legumes.

\section{Materials and methods}

\section{Materials}

Media constituents were acquired from HiMedia Laboratories, India. $\rho$-Nitrophenyl-a $\alpha$-D-galactopyranoside ( $\rho$ NPGal), Stachyose, Phenyl Methyl Sulphonyl Flouride (PMSF) and $k$-Carrageenan were procured from SigmaAldrich Inc, USA. Ion exchange matrix-Q-Sepharose fast flow and gel filtration matrix-Sephacryl S-300 were brought from GE Healthcare, USA.

\section{Microorganisms}

Microorganisms showing $\alpha$-galactosidase activity were isolated from soil collected from sugarcane industries situated at Sangareddy, Andhra Pradesh. The cultural, morphological and biochemical characteristics of the isolate were identified according to Bergey's Manual of Determinative Bacteriology, 8th edition (Buchanan and Gibbons 1974) and confirmed by 16srRNA sequencing analysis.

Crude enzyme preparation

A loopful of the isolate G1 was inoculated into optimised fermentation medium comprising raffinose $25 \mathrm{~g} / \mathrm{L}$, tryptone $10 \mathrm{~g} / \mathrm{L}, \mathrm{K}_{2} \mathrm{HPO}_{4} 10 \mathrm{~g} / \mathrm{L}, \mathrm{MgSO}_{4} \cdot 7 \mathrm{H}_{2} \mathrm{O} 1 \mathrm{~g} / \mathrm{L}$ and $\mathrm{FeSO}_{4} \cdot 7 \mathrm{H}_{2} \mathrm{O} 1 \mathrm{~g} / \mathrm{L}(\mathrm{pH}$ 7.0). The cultures were grown at $36{ }^{\circ} \mathrm{C}$ with an agitation of $170 \mathrm{rpm}$ for $12 \mathrm{~h}$. Cells were harvested and suspended in $20 \mathrm{mM}$ Tris lysis buffer $(\mathrm{pH}$ 7.0) containing $0.3 \mathrm{~g} / 100 \mathrm{ml}$ lysozyme, $0.1 \mathrm{~g} / 100 \mathrm{ml}$ Triton X 100 and $1 \mathrm{mM} \mathrm{PMSF}$ and incubated for $1 \mathrm{~h}$ at $30^{\circ} \mathrm{C}$. The lysate was centrifuged at $10,000 \mathrm{~g}$ for $20 \mathrm{~min}$ at $4{ }^{\circ} \mathrm{C}$. The supernatant thus collected was used to determine intracellular $\alpha$-galactosidase activity.

Enzyme and total protein assay

$\alpha$-Galactosidase activity was measured according to the method of Dey et al. (1993). A reaction mixture containing $550 \mu \mathrm{l}$ of $20 \mathrm{mM}$ Tris buffer (pH 7.0), $100 \mu \mathrm{l}$ of enzyme preparation and $250 \mu \mathrm{l}$ of $0.2 \mathrm{M} p N P G a l$ was incubated at $50{ }^{\circ} \mathrm{C}$ for $10 \mathrm{~min}$ and the reaction was stopped by addition of $0.2 \mathrm{mM} \mathrm{Na} \mathrm{Na}_{3}$ and read at $405 \mathrm{~nm}$. The activity was also measured using $2 \mathrm{mM}$ raffinose as natural substrate in a reaction mixture containing $20 \mathrm{mM}$ Tris buffer ( $\mathrm{pH}$ 7.0) and enzyme preparation. The resulting amount of reducing sugar was determined by addition of 3,5-dinitrosalicylate reagent (Miller 1959) and the colour read at $540 \mathrm{~nm}$. The concentration of reducing sugar, i.e., galactose, was calculated using standard galactose curve.

One enzyme unit (U) of activity was defined as the amount of enzyme required to produce one $\mu \mathrm{mol}$ of $\rho$-nitrophenol or reducing sugars (galactose) per min under the above mentioned assay conditions.

The protein content of the enzyme preparation was determined according to the method of Lowry et al. (1951) using Bovine Serum Albumin (BSA) as standard.

\section{Purification and characterization of enzyme $\alpha$-galactosidase}

Step 1: ammonium sulphate precipitation

The precipitate obtained at $60 \%\left(\mathrm{NH}_{4}\right)_{2} \mathrm{SO}_{4}$ saturation was harvested by centrifugation at $10,000 \mathrm{~g}$ for $30 \mathrm{~min}, 4{ }^{\circ} \mathrm{C}$. The pellet obtained was dissolved in $20 \mathrm{mM}$ Tris- $\mathrm{HCl}$ buffer (pH 7.2) and dialysed at $4{ }^{\circ} \mathrm{C}$ with three changes of buffer at $4{ }^{\circ} \mathrm{C}$.

Step 2: ion exchange chromatography

The dialyzed sample was loaded on to Q-Sepharose fast flow column with a bed height of $9 \mathrm{~cm}$ and internal diameter of $0.5 \mathrm{~cm}$ which was previously equilibrated with $20 \mathrm{mM}$ Tris- $\mathrm{HCl}, \mathrm{pH} 7.2$ and a flow rate of $1 \mathrm{ml} / \mathrm{min}$. The column was washed with three bed volumes of $20 \mathrm{mM}$ Tris- $\mathrm{HCl}, \mathrm{pH} 7.2$ to remove unbound protein. The bound proteins were eluted using $\mathrm{NaCl}$ gradient from 0.1 to $1 \mathrm{M}$. Both unbound and bound fractions were concentrated and analysed for $\alpha$-galactosidase activity using $\rho N P G a l$ as substrate.

Step3: gel filtration chromatography

The fractions showing $\alpha$-galactosidase activity were concentrated and loaded on to Sephacryl S-300 gel filtration column $(1 \times 90 \mathrm{~cm})$ pre-equilibrated with $20 \mathrm{mM}$ Tris$\mathrm{HCl}, \mathrm{pH}$ 7.2. $1 \mathrm{ml}$ fractions were collected at a flow rate of $0.5 \mathrm{ml} / \mathrm{min}$. Fractions exhibiting activity were concentrated and analysed for purity by PAGE. 
Native and SDS-PAGE electrophoresis

SDS Polyacrylamide gel electrophoresis was performed in $10 \%$ gels to determine molecular mass and purity of the enzyme (Laemmli 1970).

The enzyme was also electrophoresed in Native $10 \%$ gels to check for purity (Davis 1964). The protein bands were visualised by staining with Coomassie Brilliant Blue 250 .

\section{pH optimum}

The $\mathrm{pH}$ optima for activity of the enzyme was assessed by monitoring the enzyme activity in different buffers with $\mathrm{pH}$ ranging from 5.0 to 11.0 -citrate phosphate buffer $(\mathrm{pH}$ 5.0-7.0), Tris- $\mathrm{HCl}$ buffer (pH 7.0-9.0) and glycine- $\mathrm{NaOH}$ buffer ( $\mathrm{pH}$ 9.2-11.0). The $\mathrm{pH}$ stability of the purified enzymes Ag-I \& II was analysed by incubating them indifferent buffers with $\mathrm{pH}$ values ranging from 5 to 11 for a time period of 1 to $24 \mathrm{~h}$ at $36^{\circ} \mathrm{C}$.

Temperature optimum, stability and half-life

The temperature optima for maximal activity of the pure enzyme was determined by incubating the reaction mixture at different temperatures ranging from 30 to $90{ }^{\circ} \mathrm{C}$ in Tris$\mathrm{HCl}$ buffer ( $\mathrm{pH} 7.0)$. The half-life $\left(t_{1 / 2} \mathrm{~min}\right)$ of the enzyme Ag-I was determined by incubating the enzyme at different temperatures ranging from 70 to $90{ }^{\circ} \mathrm{C}$ for $5 \mathrm{~h}$.

\section{Determination of kinetic constants}

The kinetic parameters, $K_{\mathrm{m}}, V_{\max }$ and $K_{\text {cat }}$ values of the purified $\alpha$-galactosidase enzyme Ag-I and Ag-II were determined from Lineweaver-Burk plot. The rate of hydrolysis was determined with concentration ranging from 0.4 to $2.8 \mathrm{mM}$ for both the substrates $-p$-nitrophenyl$\alpha$-D-galactopyranoside ( $p$ NPGal) and raffinose against enzyme activity. The reaction was carried out at $50{ }^{\circ} \mathrm{C}$ in $20 \mathrm{mM}$ tris buffer, pH 7.0. A graph was plotted with $1 / \mathrm{v}$ versus $1 / \mathrm{s} . K_{\mathrm{m}}$ and $V_{\max }$ values were calculated based on linear regression slope. Further $K_{\text {cat }}$ value was calculated using formula

$k_{\mathrm{cat}}=V_{\max } / E_{\mathrm{t}}$,

where $E_{\mathrm{t}}$ is the total enzyme concentration.

Influence of metal ions, inhibitors and surfactants on $\alpha$-galactosidase activity

The influence of different metal ions such as $\mathrm{Mg}^{2+}, \mathrm{K}^{+}$, $\mathrm{Ca}^{2+}, \mathrm{Cu}^{2+}, \mathrm{Co}^{2+}, \mathrm{Ag}^{2+}, \mathrm{Hg}^{+}, \mathrm{Zn}^{2+}$ and chelator like EDTA were studied by preincubating the enzymes Ag-I \& II with
$5 \mathrm{mM}$ concentration of ions in $20 \mathrm{mM}$ Tris buffer at $\mathrm{pH} 7.0$ for $1 \mathrm{~h}$ at $36^{\circ} \mathrm{C}$ and then checking for enzyme activity.

The activity was also monitored after pre incubation with sugars like glucose, galactose, lactose, stachyose and other inhibitors like urea, PCMB ( $\rho$-Chloro-mercuric benzoic acid), $\beta$-mercaptoethanol and EDTA at a concentration of $5 \mathrm{mM}$ for $1 \mathrm{~h}$ at $36{ }^{\circ} \mathrm{C}$ and also with detergents like SDS, Triton X-100 and Tween-20 at a concentration of $1 \%$ for $4 \mathrm{~h}$.

\section{Results and discussion}

Identification of the isolate

A microorganism with the ability to produce alpha galactosidase enzyme was isolated from sugarcane waste and was identified as Acinetobacter sp., from its morphological features, biochemical characteristics and 16srRNA sequencing analysis. Industrially important enzymes-pectinases, lipases and biodegradable enzymes were reported to be synthesised by Acinetobacter species (Shafqat et al. 2015; Das and Chandran 2011).

\section{$\alpha$-Galactosidase purification and molecular weight}

The enzyme was purified by $\left(\mathrm{NH}_{4}\right)_{2} \mathrm{SO}_{4}$ precipitation, ion exchange chromatography and gel-filtration. Two forms of $\alpha$-galactosidases were resolved in gel filtration chromatography with molecular weights of $65 \mathrm{kDa}$ for $\mathrm{Ag}-\mathrm{I}$ and $37 \mathrm{kDa}$ for Ag-II (Fig. 1). Both the enzymes were monomeric (Fig. 2a, b). The enzyme recovery from the crude is shown in Table 1. Multiple forms of $\alpha$-galactosidase have been reported in both prokaryotes and eukaryotes (Pederson and Goodman 1980; Gherardini et al. 1985; Alani et al. 1989).

pH optimum and stability

Both Ag-I and Ag-II were found optimally active and stable at neutral pH. Enzyme Ag-I was highly active and stable over broad $\mathrm{pH}$ range showing more than $60 \%$ activity up to pH 9.0 with low activities at acidic pH. After $24 \mathrm{~h}$ of incubation at $36{ }^{\circ} \mathrm{C}, \mathrm{Ag}$-I retained $85 \%$ enzyme activity at $\mathrm{pH}$ 7.0, whereas Ag-II retained $52 \%$ activity (Fig. 3a, b). Most of the thermostable $\alpha$-galactosidases were reported to be stable at neutral pH (Pederson and Goodman 1980; Frank et al. 1985; Alani et al. 1989; Gote et al. 2006).

Optimum temperature and thermal stability

The purified Ag-I enzyme showed an optimum temperature between 50 and $60{ }^{\circ} \mathrm{C}$ and was able to retain more than 


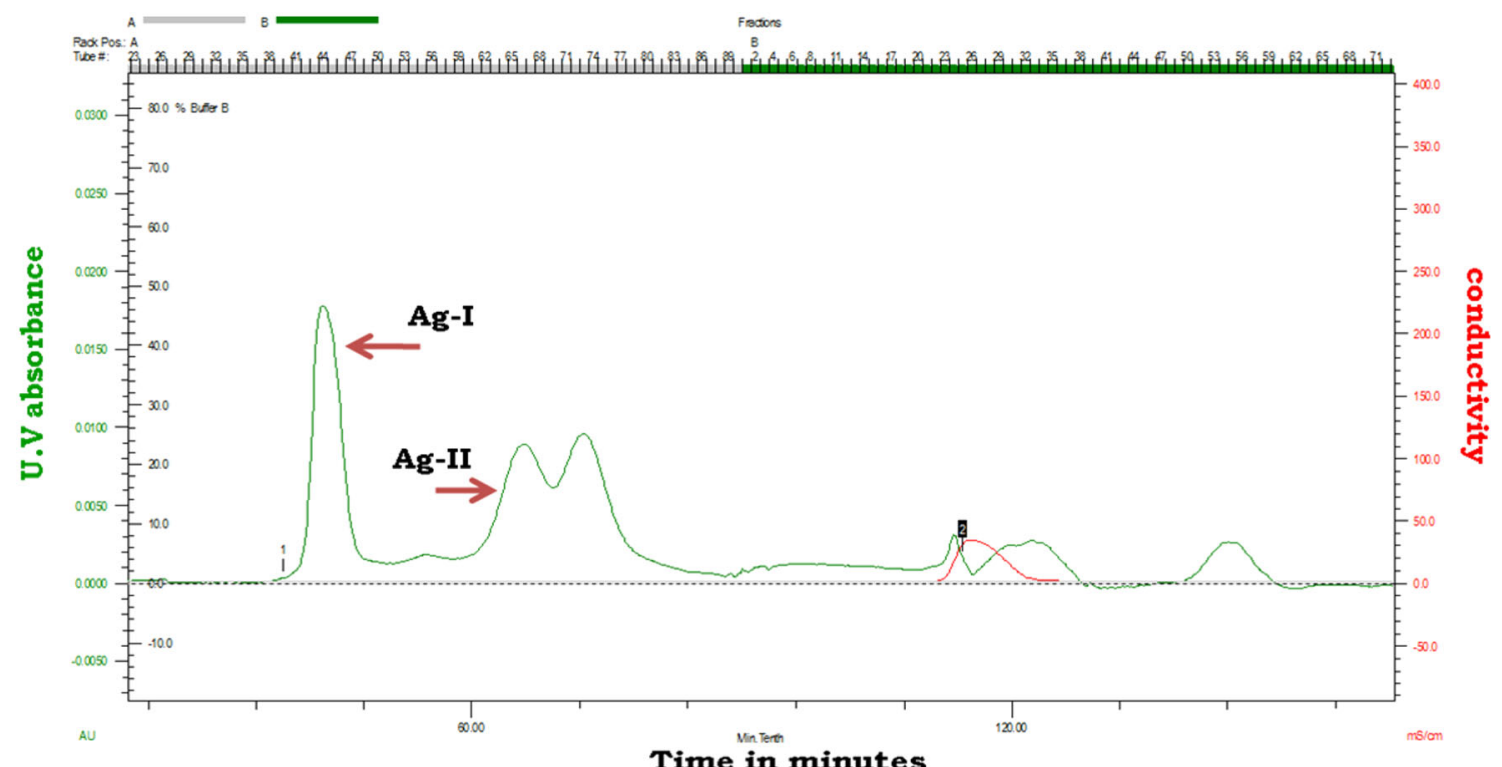

Fig. 1 Gel-filtration chromatogram of Acinetobacter sp. multiforms. Peak 1 showing higher activity was labelled as Ag I and peak 2 showing lower activity was labelled as Ag-II

Fig. 2 a, b Native and SDS PAGE analysis of purified alpha-galactosidase enzymes. a Native PAGE analysis with L1-Crude, L2-Ion exchange chromatography, L3-gel filtration, Ag-I, L4-gel filtration, Ag-II and L5-protein marker. b SDS PAGE analysis of purified alpha-galactosidase enzymes. Lane 1 Crude, lane 2 ammonium sulphate precipitation, lane 3 ion exchange chromatography, lane 4 gel filtration Ag-I, lane 5 gel filtration Ag-II and lane 6 prestained Benchmark a

$\begin{array}{lllll}\text { L1 } & \text { L2 } & \text { L3 } & \text { L4 } & \text { L5 }\end{array}$

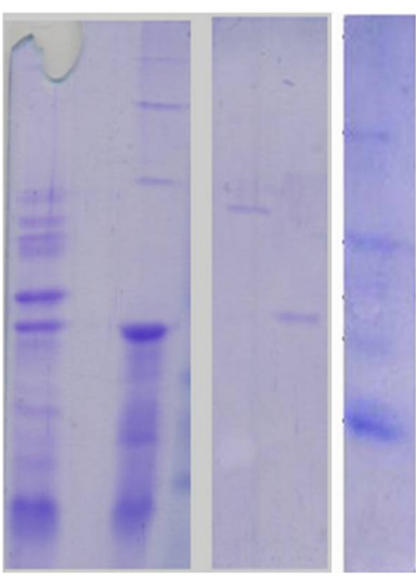

b

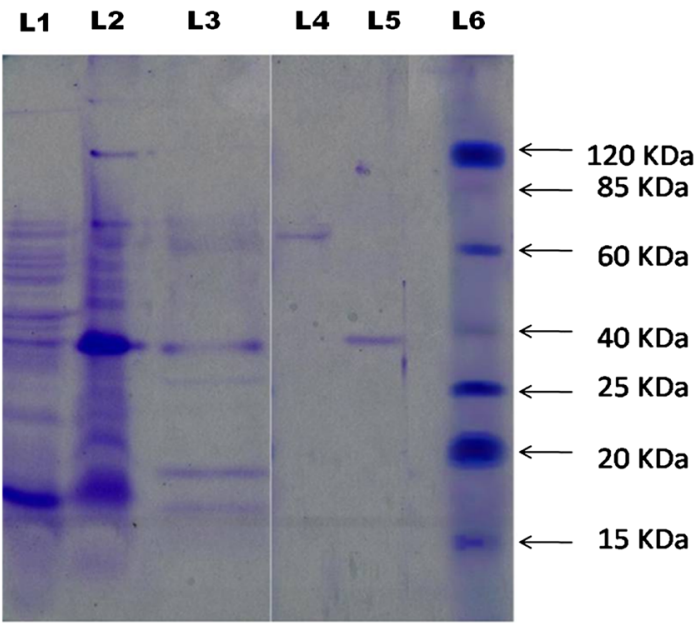

Table 1 Summary of purification studies of alpha-galactosidases isolated from Acinetobacter sp.

\begin{tabular}{lccccc}
\hline Purification step & Total protein $(\mathrm{mg})$ & Total activity $\left(\mathrm{U} \mathrm{ml}^{-1}\right)$ & Specific activity $\left(\mathrm{U} \mathrm{mg}^{-1}\right)$ & Recovery $(\%)$ & Purification fold \\
\hline Crude & 186 & 315 & 1.7 & 100 & 1 \\
$\left(\mathrm{NH}_{4}\right)_{2} \mathrm{SO}_{4}$ precipitation & 32 & 165 & 5.1 & 52.3 & 3 \\
Ion exchange & 7.8 & 71.4 & 9.2 & 22.6 & 5.4 \\
Gel filtration & & & & 10.2 & 7.0 \\
Ag-I & 2.68 & 32.4 & 12.0 & 3.8 & 4.7 \\
Ag-II & 1.52 & 12.2 & 8.0 & \\
\hline
\end{tabular}

$80 \%$ activity at $70{ }^{\circ} \mathrm{C}$ and thereafter a sharp decrease was observed at temperatures above $70{ }^{\circ} \mathrm{C}$. Ag-II displayed an optimum temperature at $40{ }^{\circ} \mathrm{C}$ but markedly decreased at higher temperatures above $60{ }^{\circ} \mathrm{C}$ (Fig. 4). The half-life of Ag-I at $70{ }^{\circ} \mathrm{C}$ was 7.69 hours and thereby decreased rapidly (Fig. 5; Table 2). $\alpha$-Galactosidases from Bifidobacterium 
Fig. $3 \mathrm{pH}$ optimium of Ag-I (a) and $\mathrm{Ag}$-II (b) after 2 and $24 \mathrm{~h}$ at $36^{\circ} \mathrm{C}$. $\mathrm{pH}$ optima was measured by incubating the enzyme with the substrate at different buffers over a $\mathrm{pH}$ range of 5.0 to 11.0

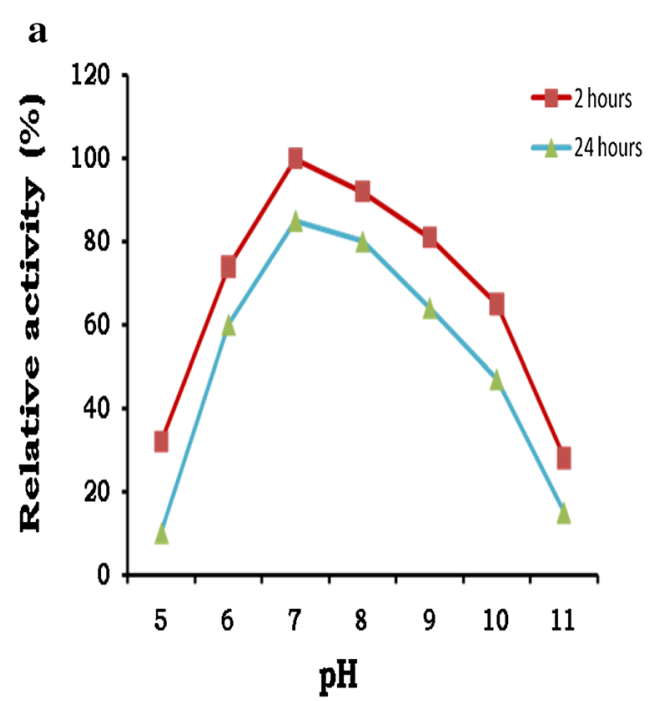

b

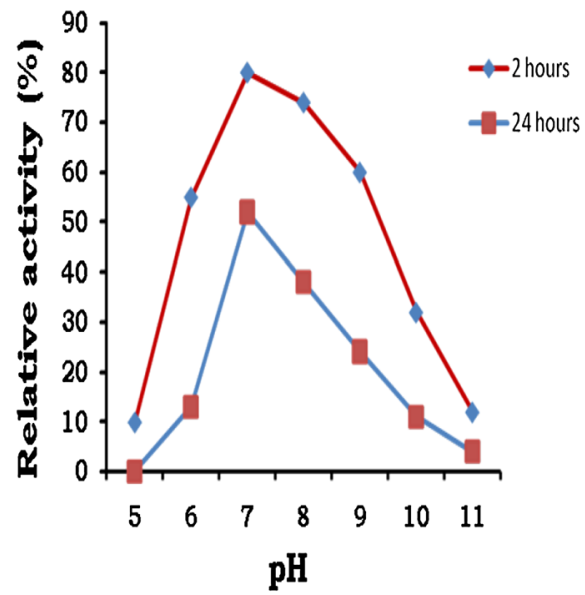

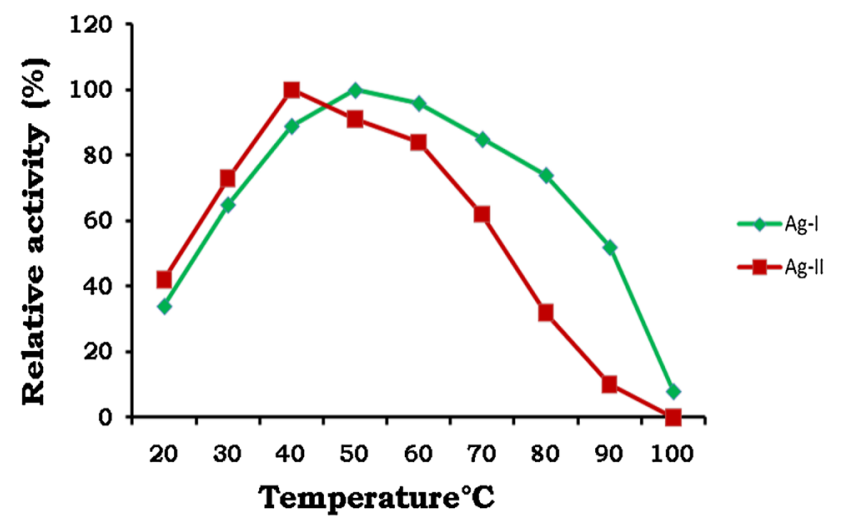

Fig. 4 Temperature optima of purified enzymes Ag-I (filled diamonds) and Ag-II (filled squares) - temperatures ranging from 30 to $90{ }^{\circ} \mathrm{C}$

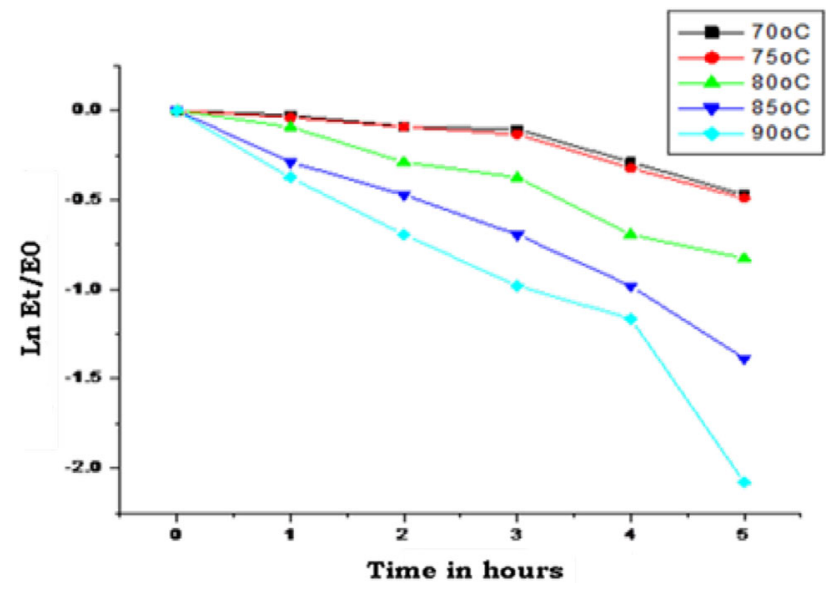

Fig. 5 Thermal stability and half-life of Ag-I. The enzyme was incubated from 70 to $90{ }^{\circ} \mathrm{C}$ for $5 \mathrm{~h}$. The half-life $\left(t_{1 / 2} \mathrm{~min}\right)$ at each temperature was calculated from $k d$ values obtained from a graphplotted in $E_{t} / E_{0}$ versus time in hours
Table 2 Half-life $\left(t_{1 / 2}\right)$ in hours calculated at temperatures $70-90{ }^{\circ} \mathrm{C}$

\begin{tabular}{lll}
\hline Temperature $\left({ }^{\circ} \mathrm{C}\right)$ & $k d$ (moles) & Half-life, $t_{1 / 2}(\mathrm{~h})$ \\
\hline 70 & 0.09009 & 7.69 \\
75 & 0.09546 & 7.26 \\
80 & 0.17209 & 4.02 \\
85 & 0.26377 & 2.62 \\
90 & 0.37283 & 1.85 \\
\hline
\end{tabular}

breve (Xiao et al. 2000) and Lactobacillus fermentum (Carrera-Silva et al. 2006) were reported to have a temperature of $50{ }^{\circ} \mathrm{C} . \alpha$-Galactosidases isolated from few hyperthermophilic bacteria were reported to be stable with half-life ranging from 6 to $9 \mathrm{~h}$ at $85^{\circ} \mathrm{C}$ (Miller et al. 2001; Duffaud et al. 1997) and $17 \mathrm{~h}$ at $80^{\circ} \mathrm{C}$ (Giuseppin et al. 1993). Even in the present study the enzyme Ag-I had shown high thermal stability which can be further exploited for processing of legumes at higher temperatures.

Effect of metal ions on enzyme activity

Assay of enzyme activity in the presence of different metal ions, sugar and non-sugar inhibitors and detergents indicated that both the enzymes (Ag I \& II) were completely inhibited by $\mathrm{Ag}^{2+}, \mathrm{Hg}^{+}$and partially in presence of $\mathrm{Cu}^{2+}$. $\mathrm{Mg}^{2+}$ and $\mathrm{Co}^{2+}$ stimulated activity whereas other metal ions showed greater than or equal to $90 \%$ activity (Fig. 6). With respect to Ag II the activity was found to be reduced between 75 and $60 \%$ in the presence of metal ions $-\mathrm{K}^{+}$, $\mathrm{Ca}^{2+}$ and $\mathrm{Zn}^{2+}$. Ag-I \& II were neither not strongly stimulated by metal ions nor inhibited by EDTA, indicating that it does not require any cofactor for enzyme activity. $\alpha$-Galactosidases isolated from different bacterial species 
Fig. 6 Effect of metal ions on purified enzymes Ag-I \& Ag-II. The metal ions at a final concentration of $5 \mathrm{mM}$ were preincubated with the purified enzyme in $20 \mathrm{mM}$ tris buffer, $\mathrm{pH} 7.0$ for $1 \mathrm{~h}$ at $36{ }^{\circ} \mathrm{C}$

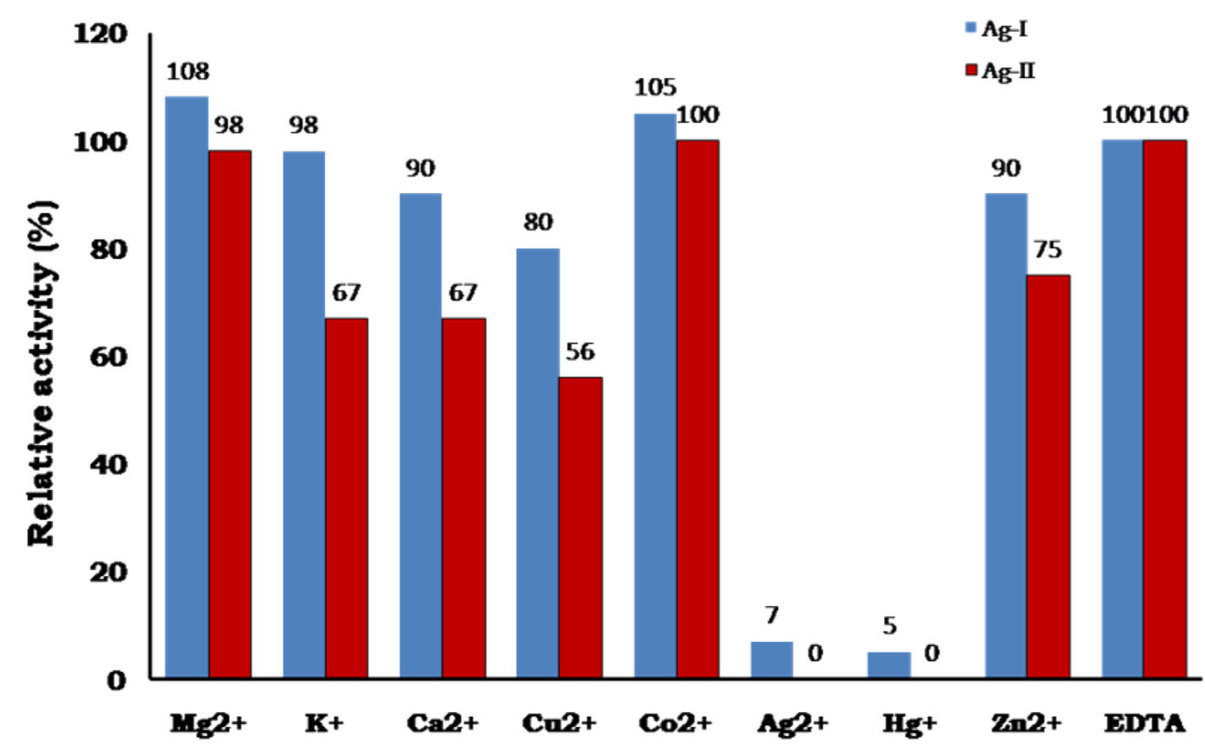

Table 3 Effect of inhibitors on purified enzymes, Ag-I and Ag-II

\begin{tabular}{lcc}
\hline Inhibitors & \multicolumn{2}{c}{ Relative activity (\%) } \\
\cline { 2 - 3 } & Ag-I & Ag-II \\
\hline Control & 100 & 100 \\
Sugar inhibitors $(5 \mathrm{mM})$ & & \\
Glucose & 82 & 75 \\
Galactose & 92 & 72 \\
Lactose & 74 & 70 \\
Stachyose & 71 & 63 \\
Non-sugars (5 mM) & & \\
PCMB & 0 & 0 \\
Urea & 100 & 92 \\
Beta-mercaptoethanol & 88 & 74 \\
EDTA & 100 & 100 \\
Surfactants (1 \%) & & 0 \\
SDS & 0 & 100 \\
Triton X-100 & 110 & 100 \\
Tween-20 & 128 &
\end{tabular}

Sugar and non-sugar inhibitors are incubated with purified enzymes at a concentration of $5 \mathrm{mM}$ for $1 \mathrm{~h}$ at $36^{\circ} \mathrm{C}$. Detergents are incubated at a concentration of $1 \%$ for $4 \mathrm{~h}$

were reported to be strongly inhibited by $\mathrm{Ag}^{2+}, \mathrm{Hg}^{+}$ions and $\mathrm{Cu}^{2+}$ (Fridjonsson et al. 1999; Zhao et al. 2008; Akiba and Horikoshi 1976). Chinen et al. (1981) suggested that the inhibition may be due to reaction with amino, carboxyl and imidazolium group of histidine present at the enzyme active site.

Effect of inhibitors and surfactants

The activity of enzymes (Ag-I \& II) was decreased from 20 to $30 \%$ in the presence of sugar inhibitors-glucose,
Table 4 Kinetic constants of purified soluble enzymes Ag-I and AgII with natural substrate, raffinose and synthetic substrate pNPGal

\begin{tabular}{|c|c|c|c|c|}
\hline Substrates & $\begin{array}{l}\text { Maximum } \\
\text { velocity }\left(V_{\max }\right) \\
\mu \mathrm{M} \min ^{-1} \mathrm{ml}^{-1}\end{array}$ & $\begin{array}{l}\text { Michaelis } \\
\text { constant } \\
\left(K_{\mathrm{m}}\right) \\
\mathrm{mM} \mathrm{ml}^{-1}\end{array}$ & $\begin{array}{l}\text { Turnover } \\
\text { number } \\
\left(K_{\text {cat }}\right) \\
\text { min }^{-1}\end{array}$ & $\begin{array}{l}\text { Specificity } \\
\text { constant } \\
\left(K_{\mathrm{cat}} / K_{\mathrm{m}}\right) \\
\mathrm{mM}^{-1} \mathrm{~min}^{-1}\end{array}$ \\
\hline \multicolumn{5}{|c|}{ Alpha-galactosidase I (Ag-I) } \\
\hline$\rho N P G a l$ & 14.51 & 0.33 & $4.45 \times 10^{2}$ & $13.48 \times 10^{2}$ \\
\hline Raffinose & 27.24 & 3.26 & $1.1 \times 10^{2}$ & $0.33 \times 10^{2}$ \\
\hline \multicolumn{5}{|c|}{ Alpha-galactosidase II (Ag-II) } \\
\hline$\rho N P G a l$ & 6.73 & 0.68 & $1.52 \times 10^{2}$ & $2.23 \times 10^{2}$ \\
\hline Raffinose & 5.44 & 0.74 & $0.6 \times 10^{2}$ & $0.81 \times 10^{2}$ \\
\hline
\end{tabular}

galactose, lactose and stachyose (Table 3). The observed decrease in activity may be due to competitive inhibition by sugars (Zapater et al. 1990). Similar observation of substrate/product inhibition by various sugars was reported in other $\alpha$-galactosidases from bacterial and fungal species (Gote et al. 2006; Falkoski et al. 2006). Triton X-100 and Tween-20 enhanced the activity of Ag I. A slight decrease in activity was observed in the presence of Beta-mercaptoethanol. Both the enzymes were also strongly inhibited by $\mathrm{pCMB}$, a thiol modifier and SDS. Inhibition by pCMB may be due to reaction with thiol groups at active site (Dey and Pridham 1972; Gote et al. 2006) and that of SDS may be due to strong affinity to proteins and its denaturing property (Falkoski et al. 2006).

Determination of kinetic constants for soluble enzyme Ag-I \& II

The kinetic constants for both the forms of $\alpha$-galactosidases are shown in Table 4. Both enzymes Ag-I and Ag-II 
have a higher affinity to synthetic substrate pNPGal (low $K_{\mathrm{m}}$ value) as compared with natural substrate raffinose. The rate of hydrolysis is high for raffinose (Ag-I) although the $K_{\mathrm{m}}$ value is high compared to synthetic substrate indicating that although the affinity is low, the catalytic processing is higher for the substrates.

\section{Conclusion}

Multiple forms of intracellular $\alpha$-galactosidases (Ag I \& II) isolated from Acinetobacter sp. were purified to homogeneity. Of both the enzymes, Ag I was found to be thermostable up to $70^{\circ} \mathrm{C}$. This enzyme has potential applications of these enzyme preparations in high temperature catalytic processes.

Acknowledgments The authors thank JNTUH for financial support.

Conflict of interest The authors declare that they have no conflict of interest.

Open Access This article is distributed under the terms of the Creative Commons Attribution License which permits any use, distribution, and reproduction in any medium, provided the original author(s) and the source are credited.

\section{References}

Akiba T, Horikoshi K (1976) Properties of $\alpha$-galactosidase of alkalophilic bacteria. Agric Biol Chem 40:1851-1855

Alani SR, Smith DM, Markakis P (1989) Alpha galactosidases of Vigna unguiculata. Phytochemistry (Oxford) 28(8):2047-2052

Buchanan RE, Gibbons NE (eds) (1974) Bergey's manual of determinative bacteriology, 8th edn. The Williams and Wilkins Company, Baltimore

Carrera-Silva EA, Silvestroni A, LeBlanc JG, Piard JC, deGiori GS, Sesma F (2006) A thermostable alpha-galactosidase from Lactobacillus fermentum CRL722: genetic characterization and main properties. Curr Microbiol 53:374-378

Chen M, Mustapha A (2012) Survival of freeze-dried microcapsules of $\alpha$-galactosidase producing probiotics in a soy bar matrix. Food Microbiol 30(1):68-73

Chinen I, Nakamura T, Fukuda N (1981) Purification and properties of $\alpha$-galactosidase from immature stalks of Saccharum officinarum (sugar cane). J Biochem 90:1453-1461

Clarke JH, Davidson K, Rixon JE, Halstead JR, Fransen MP, Gilbert HJ, Hazlewood GP (2000) A comparison of enzyme-aided bleaching of softwood paper pulp using combinations of xylanase, mannanase and alpha-galactosidase. Appl Microbiol Biotechnol 53(6):661-667

Das N, Chandran P (2011) Microbial degradation of petroleum hydrocarbon contaminants: an overview. Biotechnol Res Int 2011:941810

Davis PJ (1964) Disc electrophoresis II. Methods and application to human serum protein. Ann N Y Acad Sci 121:404-447

del Campillo E, Shannon LM (1982) An $\alpha$-galactosidase with hemagglutinin properties from soybean seeds. Plant Physiol 69(3):628-631
Desnick RJ (2004) Enzyme replacement therapy for Fabry disease: lessons from two alpha-galactosidase A orphan products and one FDA approval. Expert Opin Biol Ther 4(7):1167-1176

Dey PM, Pridham JB (1972) Biochemistry of $\alpha$-galactosidases. Adv Enzymol Relat Areas Mol Biol 36:91-130

Dey PM, Patel S, Brownleader MD (1993) Induction of $\alpha$-galactosidase in Penicillium ochrochloron by guar (Cyamopsis tetragonobola) gum. Biotechnol Appl Biochem 17:361-371

Duffaud GD, McCutchen CM, Leduc P, Parker KN, Kelly RM (1997) Purification and characterization of extremely thermostable $\beta$ mannase, $\beta$-mannosidase and $\alpha$-galactosidase from the hyperthermophilic eubacterium Thermotoga neapolitana 5068. Appl Environ Microbiol 63:169-177

Falkoski DL, Guimaraes VM, Callegari CM, Reis AP, De Barros EG, De Rezende ST (2006) Processing of soybean products by semipurified plant and microbial alpha-galactosidases. J Agric Food Chem 54:10184-10190

Frank G, Martin B, Abigail SA (1985) Purification and characterization of two $\alpha$-galactosidases associated with catabolism of guar Gum and other $\alpha$-galactosides by Bacteroides ovatus. J Bacteriol 161:500-506

Fridjonsson O, Watzlawick H, Gehweiler A, Mattes R (1999) Thermostable $\alpha$-galactosidase from Bacillus stearothermophilus NUB 3621: cloning, sequencing and characterization. FEMS Microbiol Lett 176:147-153

Gao Z, Arthur AS (1999) A novel alkaline $\alpha$-galactosidase from melon fruit with a substrate preference for raffinose. Plant Physiol 119(3):979-988

Gao HW, Li SB, Bao GQ, Tan YX, Wang YL, Zhang YP, Ji SP, Gong F (2011) Properties of a novel $\alpha$-galactosidase from $B$. fragilis and its potential for human blood-type $\mathrm{B}$ to $\mathrm{O}$ conversion. Sci Sin Vitae 41(10):1030-1036

Gherardini F, Babcock M, Salyers AA (1985) Purification and characterization of two $\alpha$-galactosidases associated with catabolism of guar Gum and other $\alpha$-galactosides by Bacteroides ovatus. J Bacteriol 161:500-506

Giuseppin ML, Almkerk JW, Heistek JC, Verrips CT (1993) Comparative study on the production of guar $\alpha$-galactosidase by Saccharomyces cerevisiae SU50B and Hansenula polymorpha $8 / 2$ in continuous cultures. Appl Environ Microbiol 59:52-59

Gote MM, Khan MI, Gokhale DV, Bastawde KB, Khire JM (2006) Purification, characterization and substrate specificity of thermostable alpha-galactosidase from Bacillus stearothermophilus (NCIM-5146). Process Biochem 41:1311-1317

Kato K, Ikami T, Kono H, Yamauchi R, Ueno Y (1982) Transferase action of alpha-galactosidase from tubers of Stachys affinisi. Agric Biol Chem 46:1089-1090

Laemmli UK (1970) Cleavage of structural proteins during assembly of head of bacteriophage T4. Nature 227:680-685

Liu X, Champagne CP, Lee BH, Boye JI, Casgrain M (2014) Thermostability of probiotics and their $\alpha$-galactosidases and the potential for bean products. Biotechnol Res Int 2014:21 pp

Lowry OH, Rosebrough NJ, Farr AL, Randall RJ (1951) Protein measurement with the Folin phenol reagent. J Biol Chem 193(1):265-275

Miller GL (1959) Use of dinitrosalicyclic acid reagent for determination of reducing sugar. Anal Chem 31:426-428

Miller ES, Parker KN, Liebl W, Lam D, Callem W, Snead MA, Mathur EJ, Short JM, Kelly RM (2001) $\alpha$-Galactosidases from Thermotoga species. Methods Enzymol 330:246-260

Naumoff DG (2001) Sequence analysis of glycosyl hydrolases: 13-fructosidase and agalactosidase superfamiJies. GlycoconjugateJ 18: 109

Naumoff DG (2004) The $\alpha$-galactosidase superfamily: Sequence based classification of $\alpha$-galactosidases and related glycosidases. 
In: Proc. Fourth Int. Conf. on Bioinformatics of Genome Regulation and Structure, pp 25-30

Patil AG, Praveen Kumar SK, Mulimani VH, Veeranagouda Y, Lee K (2010) $\alpha$-Galactosidase from Bacillus megaterium VHM1 and its application in removal of flatulence-causing factors from soymilk. J Microbiol Biotechnol 20:1546-1554

Pederson DM, Goodman RE (1980) Isozymes of alpha-galactosidase from Bacillus stearothermophilus. Can J Microbiol 26(8):978-984

Puchart V, Vrsanska M, Bhat MK, Biely P (2001) Purification and characterization of alpha-galactosidase from a thermophilic fungus Thermomyces lanuginosus. Biochim Biophys Acta 1524(1):27-37

Saishin N, Ueta M, Wada A, Yamamoto I (2010) Purification and characterization of $\alpha$-galactosidase I from Bifidobacterium longum subsp. longum JCM 7052. J Biol Macromol 10(1):13-22

Shafqat I, Shahzad S, Yasmin A (2015) Microbial potential of lipase production from different industrial effluents. J Appl Biol Sci 9(1):15-19

Singh N, Kayastha AM (2012) Purification and characterization of $\alpha$ galactosidase from white chickpea (Cicer arietinum). J Agric Food Chem 60(12):3253-3259
Tsuboi K, Yamamoto H (2012) Clinical observation of patients with Fabry disease after switching from agalsidase beta (Fabrazyme) to agalsidase alfa (Replagal). Genet Med 14(9):779-786

Xiao M, Tanaka K, Qian XM, Yamamoto K, Kumagai H (2000) High yield production and characterization of $\alpha$-galactosidase from Bifidobacterium breve grown on raffinose. Biotechnol Lett 22:747-751

Yamane T (1971) Decomposition of raffinose by $\alpha$-galactosidase. An enzymatic reaction applied in the factory-process in Japanese beet sugar factories Sucr Belge Sugar Ind Abstr 90:345-348

Zapater IG, Ullah AH, Wodzinski RJ (1990) Extracellular $\alpha$ galactosidase from Aspergillus ficuum NRRL3135 purification and characterization. Prep Biochem 20:263-296

Zeyland J, Gawronska B, Juzwa W, Jura J, Nowak A, Slomski R, Smorag Z, Szalata M, Wozniak A, Lipinski D (2013) Transgenic pigs designed to express human $\alpha$-galactosidase to avoid humoral xenograft rejection. J Appl Genet 54(3):293-303

Zhao H, Lu L, Xiao M, Wang Q, Lu Y, Liu C, Wang P, Kumagai H, Yamamoto K (2008) Cloning and characterization of a novel alphagalactosidase from Bifidobacterium breve 203 capable of synthesizing gal-alpha-1,4 linkage. FEMS Microbiol Lett 285:278-283 